Satyra a proroctwo $w$ wierszach elekcyjnych ostatniego bezkrólewia. Uwagi o intertekstualności

Wojciech Kaliszewski 
nAPIS Seria XIV 2008

\author{
Wojciech Kaliszewski
}

\title{
Satyra a proroctwo w wierszach elekcyjnych ostatniego bezkrólewia. Uwagi o intertekstualności
}

W 1adomość o śmierci króla Augusta III nie byla dla nikogo zaskoczeniem. Stary i schorowany monarcha dożywał swoich dni w atmosferze powszechnej niecierpliwości. Na tę widomość czekano w polskich obozach politycznych, jak na hasło do wymarszu na pole elekcyjne, aby ostatecznie stoczyć na nim zaciętą bitwę o koronę Rzeczypospolitej. Król umarł 5 października 1763 roku w trakcie przygotowywania uroczystości mających uświetnić trzydziestą rocznicę jego wyboru na tron polski.

Śmierć Augusta kładła ostatecznie kres kilkudziesięcioletniemu panowaniu Sasów w Polsce. Kończyła się rzeczywistość, która mimo wszelkich zawirowań i zmienności, sporów wewnętrznych i wojennych dramatów, była jednak w miarę stabilna i - co najważniejsze - przewidywalna w swym rozwoju. Ten świat, najdokładniej odbity w Kitowiczowskim lustrze, żegnano więc także z nietajonymi obawami o to, co teraz nastąpi. Zdarzyć się bowiem mogło wszystko, i przeciętnego statystę ówczesnej sceny dziejowej dręczyły wizje niejasnej przyszłości. W gabinetach politycznych układano tajne scenariusze działań, oceniano siły przeciwników, liczono sprzymierzeńców - ale na zewnątrz, wśród przygotowującej się do wypełnienia publicznych obowiązków szlachty, górę brały emocje i do głosu dochodziły — jak zwykle w takich okolicznościach — krążące w odpisach lub druczkach prognostyki, przepowiednie, pamflety i paszkwile. To one - w dużej mierze — odpowiadały za kształtowanie postaw szlacheckiej rzeszy elektorów. Było to bardzo charakterystyczne użycie języka. Można uznać, że wiersze elekcyjne były działaniem poprzez język w takim sensie, w jakim wyjaśnia ten mechanizm John L. Austin ${ }^{1}$.

1 Ten typ wypowiedzi budują tak częste w wierszach elekcyjnych zdania oznaczające działanie lub stwierdzające dokonanie się określonych faktów: 
Wiersze polityczne umożliwiały i uruchamiały w określonych sytuacjach napięć zewnętrznych typ komunikacji, który wpisany był w tradycję kultury sarmackiej². Tak więc „rozpoznawalność” funkcji tekstu łączyla się z umiejętnością wytwarzania i reprodukowania jego odmian w granicach obowiązujących wówczas konwencji. Takie „rozpoznanie” musiało odnosić się bezwzględnie do wszystkich poziomów utworu. Ramy gatunkowe obejmowały — na niższym piętrze struktury tekstowej — odpowiednio wyselekcjonowany język, powiązany regułami figur, które z kolei uruchamiały określone reakcje odbiorców. To byla - można powiedzieć - pewna „stała edukacyjna" obecna w świecie szlacheckim. Silne związki tekstu ze światem osobowym wymagają z kolei uwzględnienia ich obecności w kręgu szeroko rozumianych zagadnień biograficznych. Gry polityczne toczące się między uczestnikami wydarzeń pozwalały na zakładanie różnego kształtu i znaczenia masek, pozwalały na stosowanie zaskakujących skojarzeń i porównań, uwzględniały także potrzebę rozumienia słowa jako środka wywołującego obraz przyszłości. Ale zawsze był to świat ludzi żywych, pełnych temperamentu i gotowych do konfrontacji z przeciwnikami.

Spośród znaczących i komentowanych wierszami wydarzeń, wybór nowego władcy stanowił szczególny powód do poruszenia i nakreślenia tych perspektyw. Profetyczna rola języka objawiała się — jak wiadomo — w chwilach szczególnych napięć politycznych. Konkretny moment historyczny przeistaczał się wówczas w wyobraźni zbiorowej w symboliczne ogniwo ponaddziejowego porządku, który wypadki przenosił z poziomu ontologicznego na poziom aksjologiczny. W nieco innym ujęciu było to przesunięcie z poziomu historii na poziom historiozofii. Na plan pierwszy wysuwało się więc moralne kryterium sprawdzające wartość słowa, zaś jego relacja do tego, co trwa jako istnienie, tracila moc. Słowo przepowiadające, oderwane od pojęć wypracowanych przez rozum, rekompensowało brak jasno przewidywalnego rozwoju wypadków i pozwalało na wpisanie całej sytuacji w plan całkowicie niezależny od człowieka ${ }^{3}$. Co więcej, w tym wypadku zawieszano

Uciekam się do nieba i wylewam modły,

Związki małżeństwa jedność o tron by przywiodły.

U Austina czytamy: „Otóż wypowiedzi tego rodzaju nazywamy wypowiedziami performatywnymini. Jest to brzydkie i nowe słowo, ale, jak się wydaje, nie istniało dotąd słowo, które spełniałoby tę rolę. Według mojego rozeznania, najbliższy pełnienia tej roli jest używany przez prawników termin "wyrażenie dokonawcze»". Por. J. L. Austin, Mówienie i poznanie. Rozprawy i wykłady filozoficzne, opr. B. Chwedeńczuk, J. Woleński, Warszawa 1993, s. 311-334.

${ }^{2}$ T. Ulewicz, Sarmacja. Zagadnienie sarmatyzmu w kulturze i literaturze polskiej (problematyka ogólna i zarys historyczny), Kraków 2006. Szczególnie interesujące są zawarte w tej monografii uwagi o rozkładzie tradycji sarmackiej. Wiersze elekcyjne ostatniego bezkrólewia — w świetle tych uwag — reprezentowałyby więc tę schyłkową fazę sarmatyzmu.

3 Por. rolę prognostyków w literaturze czasów konfederacji barskiej. Stanowiły one istotny składnik „folkloru szlacheckiego". Zob. J. Maciejewski, Wstęp do: Literatura barska (Antologia), Wrocław 1976 (BN I 108). 
zazwyczaj rozróżnienie między prawdą a fałszem. Prawdziwe stawało się to, co poprzez opis w pełni pozwalało się odnieść do kreowanej sytuacji politycznej. Obraźliwe określenia i porównania, tak charakterystyczne dla paszkwilu elekcyjnego, tworzyły obrazy, które przecież w rzeczywistości nie istniały. Stanisław Poniatowski, pretendent do korony w 1764 roku, w niczym nie przypominal cielca, a był nim powszechnie — ze względu na herbowe zwierzę - nazywany. Tworzona w ten sposób klasyfikacja wysuwała twierdzenia, które za Austinem nazwać można „skandalicznymi”. Było to bowiem mówienie o czymś, co nie istnieje, czego nie $\mathrm{ma}^{4}$. Było to - po prostu — raniące działanie słowem. W tym miejscu warto więc podkreślić, że oto zarysowała się wspólna rama, obejmująca słowne działanie profetyczne i słowne działanie o charakterze satyryczno-paszkwilanckim.

Tak ujęte wydarzenia i osoby nabierały znaczeń ponaddoczesnych i stanowily wykładnię porządku uniwersalnego. Warto w tym miejscu przypomnieć, że profetyzm jako dominanta poezji politycznej zyskał szczególną wagę w okresie konfederacji barskiej, ale jego tradycje są znacznie starsze, sięgają baroku i najpełniej wówczas uwidoczniły się w kazaniach księdza Piotra Skargi ${ }^{5}$.

Wśród wierszy elekcyjnych ostatniego bezkrólewia 1763-1764 natrafiamy także na interesujący przykład tekstu łączącego w swej strukturze dwie wspomniane wyżej perspektywy: satyryczną i prognozującą, nakierowaną na przepowiadanie przyszłości. Jest to odnotowany w dwóch wersjach cykl wierszy prezentujących kandydatów do polskiej korony. Wersja pierwsza to cykl opatrzony tytulem Na pretendentów do korony polskiej po śmierci Augusta Trzeciego króla polskiego, wersja druga zaś zapisana została pod tytułem Wiersze na pretendentów do korony ${ }^{6}$.

Wiersz wyszedł spod pióra przeciwnika politycznego Familii. Wysuwany przez to środowisko kandydat do polskiej korony Stanisław Antoni Poniatowski, syn Stanisława Poniatowskiego i siostrzeniec książąt Czartoryskich, budził wśród republikantów szczególną niechęć. Im bardziej więc jego postać przybliżała się do tronu, tym bardziej protestowano i starano się tego pretendenta przedstawić w jak najgorszym i najmniej korzystnym świetle. Obawiano się jego bliskich i osobistych powiązań z panującą w Rosji Katarzyną, zakładając, że taki król stanie się dyspozycyjnym wykonawcą woli carycy. Opór budziły także praktyki Familii, osiągającej przewagę militarną nad opozycją właśnie dzięki wydatnej pomocy Rosji. Przeciwnicy Czartoryskich wiedzieli więc jedno — nowy król, jeśli zostanie nim Poniatowski, będzie starał się scentralizować władzę i ograniczyć pole swobód obywatelskich. Sądzono, że rozpoczęty dużo wcześniej przez Familię zamach stanu zaowocuje wprowadzeniem antywolnościowych, despotycznych

\footnotetext{
${ }^{4}$ Por. J. L. Austin, Mówienie i poznanie..., op. cit., s. 569.

${ }_{5}$ Por. S. Nieznanowski, Barokowa poezja polityczna. Propozycje badawcze, w: Problemy literatury staropolskiej, t. 3, red. J. Pelc, Wrocław 1978, s. 300.

${ }^{6}$ Obydwie wersje utworów przytaczam za: W. Kaliszewski, Kto królem będzie, czy Polak i który? Wiersze elekcyjne ostatniego bezkrólewia 1763-1764, Warszawa 2003, s. 173-177.
} 
rządów ${ }^{7}$. Poniatowski nie gwarantował status quo, był nieprzewidywalny, i tę cechę starano się w sposób bezwzględny i niebudzący u odbiorców wątpliwości wyeksponować.

Wiersz rozpoczyna rozbudowane porównanie, które poprzez mitologiczny sztafaż wywołuje poczucie literackiej przesady, ale zarazem godzi strzałą kpiny w Poniatowskiego. Pan Olimpu, dumny Jowisz, przybierający postać byka, aby wkraść się w laski Diany i zamieniający się w labędzia, kryjąc się przed surowym okiem Junony, mimo wszystko jest królem i władcą, który budzi respekt, i umie, kiedy trzeba, podkreślić swoja pierwszoplanową pozycję. Poniatowski dla zdobycia korony gotowy jest uczynić wszystko i przystanie na każdą metamorfozę, która pomoże mu ten cel osiągnąć. Przygody miłosne Jowisza miały charakter kaprysu wielkiego władcy. Tymczasem młody stolnik, idąc jego śladami, poważnie myśli - zdaniem jego politycznych przeciwników - o zdobywaniu korony poprzez buduary i alkowy:

Ciołek Jowiszem chce być dla korony.

Ten Piast jest młody, ma szprychy i dzwona.

Oto - powiada autor w sposób nad wyraz bezpośredni — jedynym atutem ewentualnego przyszłego króla jest młodzieńcza jurność, poddawana weryfikacji w łożach wpływowych kobiet. W tym wymiarze porównanie dyskredytuje kandydata i rysuje jego zdeformowany i zdecydowanie negatywnie nacechowany portret. Temu porównaniu mial towarzyszyć nie tylko rubaszny śmiech, wzmocniony kpiną z herbowego Ciołka. Jego celem było wzbudzenie politycznej i moralnej zarazem refleksji. Dzialania przypisywane młodemu kandydatowi od początku opatrzone są etykietą czynu niskiego, niegodnego przyszłego monarchy. Zestawienie postaci Poniatowskiego z takim czynem miało wywołać poczucie dysproporcji, złamania miary i w konsekwencji budziło niechęć wśród odbiorców. Jowisz też, co prawda. „mienil się”, ale w byka zwierzę groźnie i niebezpieczne, i tym samym odpowiadające pozycji olimpijskiego boga. W tym przypadku podkreślona została właściwa relacja. Poniatowski to tylko ciołek, któremu wydaje się, że jest bykiem, ale jest to mniemanie całkowicie fałszywe. Ujawnienie tego nieporozumienia jest szyderstwem $z$ kandydata. To dwupoziomowe zestawienie opiera się na dysproporcji porównywanych stron. Wyszydzony w ten sposób pretendent do polskiej korony nie może spodziewać się szacunku zarówno przed elekcją, jak i po niej. Ciołek Poniatowski jest poza tym słaby i potrzebuje opieki. Ta kuratela też ma dwuznaczny i aluzyjny charakter:

Ma te ż fortuny koło od Birona.

Do dwóch dam ściąga, gdy te owdowiały,

Z Cielcem ślub wziąwszy, toby poszalały.

${ }^{7}$ Zob. K. Zienkowska, Stanisław August Poniatowski, Wrocław 2004, s. 111-119. 
Oczywiste przywołanie tak zwanej „sprawy kurlandzkiej” i regenta Ernesta Birona, popieranego przez Czartoryskich, miało odsłonić prawdziwe zaplecze polityczne Poniatowskiego. Stała za nim Rosja, stała za nim świeża wdowa po carze Piotrze III, która wprawdzie straciła wiele ze swoich uczuć do młodego Polaka, ale jej zła sława doskonale pasowała do czarnego portretu i czarnej legendy Poniatowskiego. Rzeczywiście cień Katarzyny będzie towarzyszył Poniatowskiemu przez wszystkie lata jego panowania.

Drugim, po poniżającej w swym skutku przemianie, składnikiem satyrycznie skonstruowanej charakterystyki kandydata jest w przytoczonym tekście wspomniana wyżej deformacja znaczenia nazwy herbowej. Pogardliwie stosowana i groteskowo zniekształcana forma herbowego Ciołka, określająca Poniatowskiego, wyraźnie naruszała porządek świata szlacheckiego. Było to naruszenie realizujące satyryczne ujęcie rzeczywistości, które podkreśla dysproporcję między aspiracjami bohatera a jego rzeczywistymi kwalifikacjami i kompetencjami. Modyfikacja słowa przesuwała postać na sam dół hierarchii szlacheckiej, a nawet wykluczała ją z tego kręgu ludzi wolnych. Oczywiście dyskredytacja Poniatowskiego była zabiegiem celowym i niewiele miała wspólnego z prawdą. Nie o nią przecież autorowi chodziło. W tym zlośliwym zestawieniu miał się przede wszystkim wyrazić stosunek części elektorów do kandydata, którzy zdawali się mówić: ,jaki kandydat — taki herb". Poniatowski porównany do cielca tracił nie tylko cechy dobrego kandydata na króla, ale także atrybuty przysługujące każdemu wolnemu obywatelowi Rzeczypospolitej zaliczono go do gatunku zwierząt nieszlachetnych. To zestawienie nabierało szczególnego istotnego znaczenia w kontekście kultury, która ze słowem - także mówionym, przekazywanym bezpośrednio w żywym kontakcie - wiązała istotne treści. Nazwanie lub przezwanie kogoś stawało się trwałym składnikiem jego rzeczywistości. Znak herbowy przylegal do pieczętującej się nim postaci. Semantyka przydomków i określeń w kulturze szlacheckiej stanowiła istotne źródło informacji o cechach i zaletach określanego człowieka. W tym wypadku była to wyraźna próba deprecjacji kandydata Familii. A po drugie porównanie to jest właśnie najlepszym przykładem stworzenia za pomocą słowa postaci, która naprawdę nie istnieje. Wszystko jednak, co na temat kandydata powiedziano, mieści się w granicach uznanych w takich sytuacjach konwencji.

Wprowadzenie postaci bóstwa olimpijskiego, Jowisza, do wiersza swoiście prezentującego kandydata do tronu i wykorzystanie go w takim kontekście, jest oczywistą antykizacją, pełni jednak także inną funkcję. Sam Jowisz przez przywołane tutaj zachowanie umożliwia wprowadzenie elementów heroikomicznych. Brak powagi, przysługującej władcy Olim$\mathrm{pu}$, przenosi się na zestawionego z nim Poniatowskiego. Jego czyny i przewagi przynależą co najwyżej do przestrzeni damskiej alkowy i dalekie są od przestrzeni pól bitewnych ${ }^{8}$.

8 Warto w tym miejscu wspomnieć o wierszach z okazji odsłonięcia pomnika Jana III Sobieskiego w Łazienkach w stulecie wiktorii wiedeńskiej. Poniatowski był w nich zdecydowanie ośmieszany i nie wytrzymywal porównania z Janem III Sobieskim. 
Zmienność, niestałość, przywdziewanie coraz to innych masek oznaczało brak trwałości i źle wróżyło w związku z tym przyszłości. Metamorfozy przyszłego króla nie odpowiadały oczekiwaniom elektorów. Taki władca „mieniący się co chwila” nie dawał rękojmi utrzymania w porządku i prawie powierzonego mu królestwa. Skłonności i przyzwyczajenia Poniatowskiego wyraźnie mijały się — to miał ukazać wiersz - z postawą przyjmowaną za wzorzec dobrego monarchy. To wyraźne pęknięcie było źródłem satyrycznego napięcia, jakie ta część wiersza niosła.

Wersja druga utworu przynosi wątek Europy. Dzieje się tak znowu za sprawą Jowiszowych historii:

Co są poetów o Jowiszu baśnie,

Nie ściągają się tu do Ciołka właśnie.

Byk czyli Ciołek, znak Europy zatem

Godzien w Europie być swej koronatem.

Wyraźnie ironiczna amplifikacja zakresu władzy ma na celu ośmieszenie rzeczywistych możliwości marzącego o koronie Poniatowskiego. Treść wiersza wariantowego wskazuje na krążące w powszechnym obiegu motywy satyryczne wymierzone w Poniatowskiego — pretendenta do korony. Jeden wszakże motyw pojawia się w obu wersjach w tej samej postaci. Jego obecność była wynikiem powszechnego przekonania, które opierało się na łączeniu kariery politycznej młodego Poniatowskiego z urokami i względami wplywowych kobiet i pomocy dworu rosyjskiego:

A przy tym szczęście wszelkie ma poboczy,

Czy na tę wdowę, czy na ową wskoczy.

Satyryczna prezentacja kandydata ocierająca się o paszkwilancką inwektywę eksponuje w tym wypadku zachowania naturalistyczne, lokuje przeciwnika politycznego na zupełnie innym, niższym - zwierzęcym - poziomie.

Postać Jowisza, stanowiąca lustro dla kandydata, boga i władcy zmiennego, ale przecież mającego moc kształtowania rzeczywistości, tutaj została celowo spłaszczona i spłycona. Jowisz przypomina postać jarmarczną, wywołującą, przez swe zachowanie, reakcję typową dla ludowego komizmu. Związanie obu postaci w tekście w całość psychologiczno-obyczajową stawia Poniatowskiego w takim samym — ludycznym kontekście. Kandydat pozbawiony powagi i charyzmy staje się natychmiast śmieszny, bezbronny i bezsilny. Zdobycie przez niego korony będzie więc uzurpacją i naruszeniem porządku obyczajowego. Zarówno jednak w pierwszej, jak i w drugiej wersji utworu przywołanie postaci Jowisza nie jest przypadkowe i nawet - powiedzmy komplikuje wizerunek pretendenta. Wladca Olimpu pojawiał się także w utworach panegirycznych, służyl podkreśleniu zalet i walorów kandydata Familii. Jowisz zmieniony w byka imponował siłą i wytrwałością. Znamy pochwałę Ciołka dźwigającego 
- niczym Jowisz Europę - całą Sarmację ${ }^{9}$. A więc wiersz jest jakby otwarty i czeka na różne - nierzadko sprzeczne — wykładnie.

Jako kontrkandydat do polskiej korony zostaje również wymieniony Mikołaj Jan Chodkiewicz, starosta żmudzki. Nie wiemy na pewno, czy myślał o tronie, ale jego nazwisko pojawiało się w czasach przedelekcyjnych polemik. Wymieniano je być może ze względu na legendę, jaka otaczała jego przodków:

Cny Chodkiewiczu, najwyższy Longinie,

Którego sława na Polesiu słynie,

Szukajże z Saulem i na wszystkie strony,

Od Samuela byś był namaszczony.

Sam Chodkiewicz poparł ostatecznie Czartoryskich, ale pomijając realia, warto zwrócić uwagę na starotestamentowe porównania. W przypadku Poniatowskiego przywolano Jowisza, budując satyryczny portret kandydata. Chodkiewicz takiej deprecjacji już nie został poddany. Przeciwnie - jego sylwetka, umieszczona w kontekście władców znanych z ksiąg Starego Testamentu, nabiera niebagatelnego znaczenia. Tym razem mamy do czynienia z zabiegiem wyolbrzymiającym postać kandydata. Warto więc zadać pytanie o sens takiej hiperbolizacji. Niewątpliwie jej celem nie jest skoncentrowanie uwagi tylko i wyłącznie na nowej kandydaturze, ale wskazuje na znacznie szerszą perspektywę. Mowa tutaj o domniemanych losach Rzeczypospolitej, które wlaśnie teraz się ważą. Tak pomyślana i skonstruowana strofa pełni więc funkcję opozycyjną w stosunku do poprzedniej, poświęconej Poniatowskiemu. Pogański Jowisz na tle starotestamentowych władców ma ograniczoną moc działania. Jego siła jest iluzoryczna i odnosi się przede wszystkim do intryg miłosnych. Tymczasem postacie Samuela i Saula wiążą się z ingerencją Boga w sprawy tego świata. Nadaje to całej kwestii zupełnie inny wymiar. Oto bowiem zbudowana została analogia pomiędzy losami Polski i narodu wybranego. To oczywiście jest analogia zawierająca wiele ostrzeżeń i przypominająca dramatyczny konflikt między Saulem a Dawidem. Namaszczenie Saula przez Samuela i powolanie pierwszego króla Izraela otwiera w dziejach nowy okres. Prorocze działania splatają się z historią i wyznaczają kierunek jej rozwoju. Postać Saula, od razu kojarząca się z Dawidem, wywołuje jakby obrazy przyszłego królestwa. Dodać jednak trzeba, że jest to obraz - ze względu na Saula - niepokojący. Kto ostatecznie będzie królem na razie jeszcze trudno powiedzieć. Ale ów ton proroczy pozwala na hipotetyczną zapowiedź:

${ }^{9}$ Por J. Pokora, Obraz Najjaśniejszego Pana Stanisława Augusta (1764-1770). Studium z ikonografii władzy, Warszawa 1993 s. 36. Przywołany został tutaj wiersz laciński Stanisława Konarskiego, który mówi właśnie o dźwiganiu Sarmacji. 
W dziele pszczół czyli miód która daje strona

Stamtąd do Polski przyplynie korona.

Wy się starajcie, byście z szlachtą żyli,

A o koronie polskiej nie myślili.

Sprawa korony polskiej wydawała się więc przesądzona. Nie ma wątpliwości, że chodzi tu o Poniatowskiego. Łączono bowiem w panegirycznych wizjach ciołka z obrazem martwego wołu, z którego lęgną się roje pszczele, gwarantujące pomyślność i dobrobyt. Sens owego przedstawienia wskazywał na niewątpliwą gotowość przyszłego króla Poniatowskiego do podtrzymywania, czy wręcz dawania życia ${ }^{10}$. Przyszły władca miał być prawdziwym źródłem dobra w królestwie. Była to więc zapowiedź ożywiająca nadzieję, potrzebna i oczekiwana. Lepiej jednak użyć w tym miejscu trybu warunkowego: by la by. Ta przepowiednia kryła i kryje bowiem w sobie ostrzeżenie przed utratą kontroli nad wypadkami politycznymi. Końcowy apel studzący wszelką aktywność, nakazujący przyjęcie postawy biernej, oczekującej, ma charakter wyraźnie dwuznaczny. Dokładniej tę dwuznaczność ujęto w wersji wtórej wiersza o kandydatach do polskiej korony:

Byłyby wprawdzie miodopłynne wieki,

Gdyby wodami płynęły pasieki,

Lecz w tym korona polska niech nie tonie,

Będziem żyć z szlachtą i z nas kto w koronie.

Pojawia się tutaj wizja przyszłości, która nie stanie się rzeczywistością. Nawet zwolennicy Czartoryskich, wspierani przez Rosję i Prusy, nie mogą zmienić obrazu natury, i wodami polskich rzek nie popłynie miód. Ten obraz ma też jednak swoją odwrotną stronę i może być rozumiany jako ostrzeżenie przed katastrofą, która zniszczy dobrobyt. W tym wypadku woda oznacza żywioł niszczący świat.

Jedna z funkcji prognozowania przyszłości państwa było wywołanie niezwykłego klimatu otaczającego wypadki. Przywiązanie do znaków i dawanych człowiekowi przez Opatrzność stanowiło ważny rys tradycji tworzącej kulturę szlachecką. Rozumiane i odczytywane w ten sposób znaki układały się w rodzaj tekstu na temat aktualnych wydarzeń, który należało odczytywać wedle kodu historiozoficznego, biorąc w nawias samą historię. W cytowanym wierszu takim wstępem do owego tekstu na temat obioru władcy jest niewątpliwie kontekst starotestamentowy, odsyłający do ksiąg pokazujących przebieg wypadków w królestwie narodu wybranego. Wiersz jest wiec rodzajem drogowskazu, który ma zaprowadzić czytelnika do właściwego źródła - to znaczy do Pisma Świętego. Dopiero uważna i wnikliwa lektura starotestamentowych ksiąg

${ }^{10}$ Chodzi tutaj o motyw odradzania pszczół z ciała martwego wołu, występujący między innymi w Georgikach Wergiliusza. Por. J. Pokora, Obraz Najjaśniejszego Pana..., op. cit., s. 36. 
— a chodzi tutaj przede wszystkim o Księgi Samuela — pozwoli naprawdę zrozumieć sens przepowiedni i wpisanej w nią wizji władzy.

Zakończenie wiersza, utrzymane w podniosłym i wręcz patetycznym tonie, ukazuje swoisty paradoks calej profetycznie skonstruowanej wykładni:

Już pomazaniec jest od Boga dany,

W pośrodku ludu będzie on poznany.

Tam gdzie szum wody czynią dźwięk i pszczoły

Ni nie pociągną ni konie, ni woły.

Doniósł król pruski i Ruś przyjaciołka:

Polacy! Królem będziecie mieć Ciołka.

Ostatni dystych przynosi załamanie podniosłej atmosfery. Oto w miejscu Opatrzności pojawiają się państwa ościenne i one ostatecznie decydują o wyborze kandydata na króla Rzeczypospolitej. Król z obcej woli staje się zwykłym narzędziem politycznym w ręku swych protektorów. W ten sposób także — satyryczny — zostaje unieważnione otwierające cykl porównanie z Jowiszem. Zakończenie odkrywa całą ukrytą wcześniej polityczną strukturę desygnowania Poniatowskiego na kandydata i w rezultacie króla Polski. Sięgnijmy raz jeszcze do wersji drugiej i przyjrzyjmy się analogicznemu fragmentowi w tej odmianie:

Z Bogiem nie gadal nikt o pomazańcu,

By już był dla nas i stanął na szańcu.

Żądł pszczół nie chcemy ani wody szumu.

Chyba ten, który mało ma rozumu.

Dalej także mowa jest o Prusach i Rosji, które ostatecznie decydują o tym, kto zasiądzie na polskim tronie. Ale tutaj zakończenie jest jednak nieco inne, i znowu zostajemy wprowadzeni na poziom typowej zodiakalnej przepowiedni:

Król pruski oraz Ruś dobrze życzy:

Niech Ciołek w Polszcze koronat się liczy.

W niebieskiej sferze Byk Korony blisko,

Między gwiazdami to mając nazwisko.

Więc gdy w niebieskiej Byk z Koroną stronie,

Niech i na ziemi jaśnieje w koronie.

Byk i Korona to widoczne razem gwiazdozbiory marcowego nieba. Pomyślny związek astrologiczny miał być dobrą wróżbą dla Polski. W tym prognostyku brzmi także echo panegirycznych pochwał przyszłego króla. Tutaj jednak, w kontekście bardzo przyziemnych ustaleń rosyjsko-pruskich, ową wróżbę astrologiczną należy traktować $z$ odpowiednim dystansem. 
Wiersze na pretendentów do korony stanowią - wraz ze swą odmianą wariantową - charakterystyczną mieszankę gatunkową i stylistyczną. Pojawiające się w tekście sprzeczności i różnice między aprobatą i dezaprobatą dla głównego bohatera, jakim był Stanisław Poniatowski, tworzą klimat rzeczywistych napięć i przeciwieństw towarzyszących dyskusjom elekcyjnym, jakie po śmierci Augusta III wszczęto w całej Rzeczypospolitej. Te zapisy warto traktować i rozumieć jako zapisy zmiennych emocji, odgrywających wielką rolę w sporach politycznych. Zarówno na satyryczny, jak i na profetyczny aspekt przywołanych wierszy składa się wiele elementów. W te dwie perspektywy wpisana została opowieść o kandydatach, a przede wszystkim o Poniatowskim, tę opowieść przekazywano sobie, zmieniając pewne jej elementy, z ust do ust, z jednego kresu Rzeczypospolitej do drugiego.

W przypadku cytowanego utworu, przemienność formuł satyrycznych i prognozujących tworzy zupełnie nową jakość znaczeniową. Powstaje dzięki tej łączności tekst, który staje zawsze ponad tekstami składowymi. Jest to rodzaj swoistego nadtekstu, w którym poszczególne części są dla siebie komentarzem, dopełniają się, dialogują ze sobą. Powstaje dzięki tym powiązaniom relacja międzytekstowa, którą można odnieść do modelu intertekstualnego, zaproponowanego niegdyś przez Gérarda Genette'a ${ }^{11}$. Pozwala to na podkreślenie wieloznaczności przywołanego tekstu i tym samym akcentuje jego wielofunkcyjność. Wiersze na pretendentów do korony, realizując dwa typy wypowiedzi — satyryczny i profetyczny — rozwijają się dzięki wewnętrznej inspiracji. Odwolanie do poetyki intertekstualnej w tym przypadku pozwala analizować wzajemne oddziaływanie dwóch odmiennych typów wypowiedzi obecnych w jednym utworze. Jest to więc swoista, „wewnętrzna” intertekstualność. Wprowadzenie tej kategorii — domagającej się jeszcze rozwinięcia — pokazuje w sposób swoisty wnętrze tekstu.

Rola satyry i wiersza prognozującego kierunek i przebieg nadchodzących wypadków w czasie bezkrólewia była niewątpliwie istotna. Było to - jak już podkreśliłem - d zi a ła n i e prowadzone za pomocą słów. W ten przecież sposób przekładano na zrozumiałe i czytelne komunikaty ważne treści polityczne, odwołując się nie tylko do dyspozycji rozumowych, ale i do emocji. Tak było w przypadku satyry politycznej zawsze ${ }^{12}$. Ale polączenie satyry z przepowiednią wzmacnia efekt oddziaływania na sferę emocji, czyni tekst bardziej skutecznym i uniwersalnym zarazem. Dotyka z jednej strony skrawka konkretnej, historycznie określonej rzeczywistości, a z drugiej ujmuje wydarzenia w planie metafizycznym, nadając wydarzeniom odpowiednio wzniosłą rangę.

\footnotetext{
${ }^{11}$ W tym wypadku wiersz o pretendentach do polskiego tronu byłby najbliższy ujęciu ,hipertekstualnemu", to znaczy takiemu, które obejmuje wszelkie trawestacje i pastisze. Por. G. Genette, Palimpsesty. Literatura drugiego stopnia. tł. A. Milecki, w: Wspótczesna teoria badań literackich za granica, opr. H. Markiewicz, t. 4, cz. 2, Kraków 1992.

12 Por. J. Nowak, Satyra polityczna sejmu czteroletniego, Kraków 1933, s. 204-206.
} 